\title{
Persistent Macroeconomic Imbalances in the Euro Area: Causes and Consequences
}

\author{
$\underline{\text { Nils Holinski, Clemens Kool, and Joan Muysken }}$
}

\begin{abstract}
In this paper, the authors document a growing divergence between current account imbalances in northern and southern euro area countries from 1992 to 2007. The imbalance occurred without a concomitant rise in productivity and growth in the southern (deficit) countries. The authors argue that systematic monitoring of external imbalances and implementation of better coordinated policies to prevent the emergence of unsustainably large imbalances in the euro area is advisable because (i) country heterogeneity and the absence of optimal currency area characteristics may lead to the emergence of large current account imbalances without automatic gains in productivity and economic growth to sustain these imbalances, (ii) the absence of sufficient market-based adjustment mechanisms substantially increases the costs of ultimate adjustment toward more sustainable current account positions, and (iii) large external imbalances-particularly through the major role of the banking system—potentially have strong negative consequences for fiscal policy. (JEL F15, F32, F41)
\end{abstract}

Federal Reserve Bank of St. Louis Review, January/February 2012, 94(1), pp. 1-20.

January 1, 1999, marked the start of the euro area and the introduction of the euro as the common currency for 11 European Union (EU) members. ${ }^{1}$ At the time, this was perceived as the final step in the European economic and monetary integration process. The European Central Bank (ECB) was established with a strict mandate to maintain price stability through the implementation of the common monetary policy. Simultaneously, the Stability and Growth Pact (SGP) set binding constraints on each member country's fiscal policy, limiting its government deficit to a maximum of 3 percent of gross domestic product (GDP) and its government debt to a maximum of 60 percent of GDP. With both monetary and fiscal policy appropriately addressed, the consensus was that the internal EU market with its free mobility of goods, capital, and labor would ensure sustainable growth and economic convergence in the euro area, even though cross-country structural differences still prevailed at its start. This article argues that the euro area actually has shown economic divergence as exemplified by growing external imbalances,

Nils Holinski is a researcher at Maastricht University. Clemens Kool is a professor of finance and financial markets at the Utrecht University School of Economics and a visiting scholar at the Federal Reserve Bank of St. Louis. Joan Muysken is a professor of economics at Maastricht University. The authors thank participants of the European Monetary Forum Conference 2010 in Bern, Switzerland; the Netherlands Network of Economics (NAKE) Research Day 2010 in Utrecht; the macro seminar at Maastricht University on May 7, 2010, and two unknown referees.

( ) 2012, The Federal Reserve Bank of St. Louis. The views expressed in this article are those of the author(s) and do not necessarily reflect the views of the Federal Reserve System, the Board of Governors, or the regional Federal Reserve Banks. Articles may be reprinted, reproduced, published, distributed, displayed, and transmitted in their entirety if copyright notice, author name(s), and full citation are included. Abstracts, synopses, and other derivative works may be made only with prior written permission of the Federal Reserve Bank of St. Louis. 


\section{Holinski, Kool, Muysken}

despite reasonably well-behaved fiscal and monetary policy, and attempts to shed light on the underlying causes of this divergence.

Until the start of the global financial crisis in 2008, ECB monetary policy did succeed in keeping inflation low and stable. On the fiscal side, the picture is more mixed; by 2002-03 it had become apparent that central EU enforcement of the agreed-upon fiscal constraints was difficult. When the two most powerful euro area countries, Germany and France, demonstrated their unwillingness to meet the SGP criteria by interfering with domestic economic conditions, the EU's leverage over other countries' behavior decreased substantially, thereby weakening the SGP constraints. Nevertheless, most euro area countries implemented reasonably conservative fiscal policies even when such policies did not strictly adhere to the SGP criteria. Implicitly, financial markets showed their approval for the fiscal consolidation in individual euro area countries as government bond risk premiums were very low and stable until 2008.

Clearly, all of this changed with the global financial crisis. Not only have all member countries since breached the self-imposed budgetary constraints of the Treaty on European Union (known informally as the Maastricht treaty), but some are even on the verge of a sovereign debt crisis. International capital markets have reacted by demanding extremely high risk premiums for holding public debt issued by Spain, Portugal, Ireland, and, more recently, Italy. Greece faces such unsustainable terms in international capital markets that it effectively can no longer access these markets. The joint euro area countries, together with the ECB and the International Monetary Fund (IMF), had to step in as lenders of last resort in May 2010 and have since been forced to further expand their rescue activities. $\underline{2}$

Obviously, it is necessary to reassess the sustainability of government finances of the euro area countries in light of the current economic environment. However, in our view, the exclusive focus on fiscal sustainability is unwarranted and insufficient to understand the issues facing the euro area. We argue that growing current account imbalances within the euro area indicate an ongoing process of economic divergence rather than convergence among euro area countries. The divergence process started with the introduction of the common currency in 1999 and cannot be confined only to the public sector. As a result, cumulative current account imbalances have substantially grown between northern and southern euro area countries. So far, euro area governments have treated these imbalances with benign neglect. In our view, this is inappropriate and unsustainable. The ultimately necessary reversal of existing imbalances will require painful adjustment, probably with a clear role for fiscal policy in both the northern and southern euro area countries and the institution of policies aimed at increasing productivity and competitiveness in southern countries. In the analysis, we focus on a group of four typical northern countries-Germany, Austria, Finland, and the Netherlands-with large and persistent current account surpluses on the one hand and a group of four typical southern countries-Greece, Portugal, Spain, and Ireland - with large and persistent current account deficits on the other. However, we stress that the policy implications extend beyond these specific countries and canand should-be generalized.

The article is organized as follows: In the following section we briefly discuss how macroeconomic external imbalances can contribute to economic convergence across countries. Subsequently, we provide a systematic review of internal and external imbalances in the euro area by differentiating the private and public sectors and their respective savings and investment behavior. 
In addition, we disaggregate euro area current accounts into trade balances, net factor income, and net current transfers. We then discuss the available empirical evidence with respect to structural convergence in the euro area and suggest routes for future research, followed by a discussion with some policy suggestions and our conclusion.

\section{CURRENT ACCOUNT IMBALANCES AND STRUCTURAL CONVERGENCE}

In the 1950s and 1960s, most developed countries participated in the Bretton Woods system of fixed exchange rates. As a result, except for the United States no country could implement an independent domestic monetary policy. The prevailing doctrine was that each country should maintain internal and external equilibrium using fiscal policy and the level of its exchange rate. The current account of the balance of payments served as a crucial indicator of the sustainability of the fixed exchange rate, while the IMF played an important role in the monitoring of unsustainable balance of payments positions, providing temporary financial support and assisting in orderly exchange rate devaluations.

Since the advent of flexible exchange rates and the development of international financial markets facilitating financial integration in the early 1970s, the concern over external imbalances has decreased and almost disappeared. In a seminal article, Feldstein and Horioka (1980) argue that increased financial integration should lead to a loosening of the relation between domestic savings and investment as countries could use the international capital market to finance savingsinvestment imbalances. Taken literally, increasing current account imbalances then should be taken as positive news, showing that financial markets are at work to improve the international allocation of capital and economic convergence across countries. Tests of the so-called FeldsteinHorioka hypothesis show that international financial integration was still far from complete in the 1970s and 1980s. However, from the 1990s onward, evidence suggests developed countries are increasingly able to use financial markets to finance domestic investment through foreign funding or invest their excess savings in foreign economies. 3

Underlying this line of thought is the theory of intertemporal utility maximization. It suggests that diverging current accounts are the natural consequence of a convergence process among countries with different levels of economic development. In particular, in the presence of integrated real and financial markets, we should expect countries with lower per capita income to attract foreign investment because their higher expected productivity growth and corresponding economic growth rate promise above-average rates of return. The productivity of the invested capital ensures that the accumulated foreign liabilities can ultimately be repaid. At the same time, these countries should consume more and consequently save less in anticipation of higher income growth in the future. As a result, these countries run current account deficits for a while, which are nothing to worry about and do not require government intervention. $\underline{4}$

In a discussion about the potential problem of large and semi-persistent current account imbalances among the G7 countries, Clarida (2007, p. 1) states that "current account imbalances in major economies with open capital markets and flexible exchange rates are a general equilibrium phenomenon." In a similar vein, Blanchard (2007, p. 3) summarizes this view-for the group of rich, developed countries-in the following way: 


\section{Holinski, Kool, Muysken}

Assume that a current account deficit reflects private savings and investment decisions. Assume rational expectations. Is there any reason for the government to intervene, and what is the optimal form of that intervention?

It is clear the answer depends on the existence and specific form of distortions in the economy. Thus, I start from a benchmark in which such distortions are absent, the equilibrium is the first-best outcome, and there is no role for government intervention.

In a world as sketched by Clarida (2007) and Blanchard (2007), any adjustment to a more balanced current account will in the end be automatically brought about by changes in exchange rates and in private investment and savings rates across countries. Then, current account imbalances would require neither special attention nor government intervention. It then comes down to the question of how much confidence one has in the underlying assumptions of rationality, sufficient economic and financial integration, and absence of substantial distortions. $\frac{5}{}$

Starting from the above theoretical framework, Blanchard and Giavazzi (2002) empirically investigate the current account deficits of the southern euro area countries and the surpluses of the northern countries. They find that financial integration in the euro area has reached a level that domestic savings and investment decisions indeed can be decoupled. In their view, this allows the southern lower-income countries to borrow extensively in support of economic convergence toward their northern neighbors and provides support for the convergence hypothesis. Although they do not see a reason for concern over persistent current account imbalances in the euro area, Blanchard and Giavazzi (2002) hesitate to define "benign neglect" as the optimal response because of the existence of serious nominal rigidities in the euro area-particularly the impossibility of nominal exchange rate adjustment-and lack of sufficiently strong fiscal policy rules. -6 Ahearne, Schmitz, and von Hagen (2007) point out that capital flows move in the direction predicted by neoclassical theory and strongly support the convergence hypothesis.

On the other hand, Arghyrou and Chortareas (2008) and Jaumotte and Sodsriwiboon (2010) express concern with respect to the sustainability of the observed current account deficits in southern euro area countries. They suggest close monitoring is in order and argue that appropriate policy responses need to be discussed. In addition, Jaumotte and Sodsriwiboon (2010) state that the average current account deficit of southern euro area countries exceeds fundamental current account norms by about 6 percent of GDP. In their view, this was facilitated by their euro area membership. They are unable to determine how much of this deficit bonus can be rationalized using the convergence argument but point out the risk of such deficits for a country's net foreign debt position.

\section{CURRENT ACCOUNT IMBALANCES IN THE EURO AREA}

In this section, we provide evidence on the actual current account developments in the euro area over the period 1992-2007. ${ }^{-}$For our empirical analysis, we largely use data from the AMECO database of the European Commission, which allows for a detailed and consistent breakdown of all relevant variables.

First, it is important to note that the current account of the euro area as a whole has been roughly balanced over the period of analysis. That is, no substantial external imbalances with the rest of the world were realized between 1992 and 2007. For this reason, we assume that we 


\section{Figure 1}

\section{Current Account (1992-2007)}

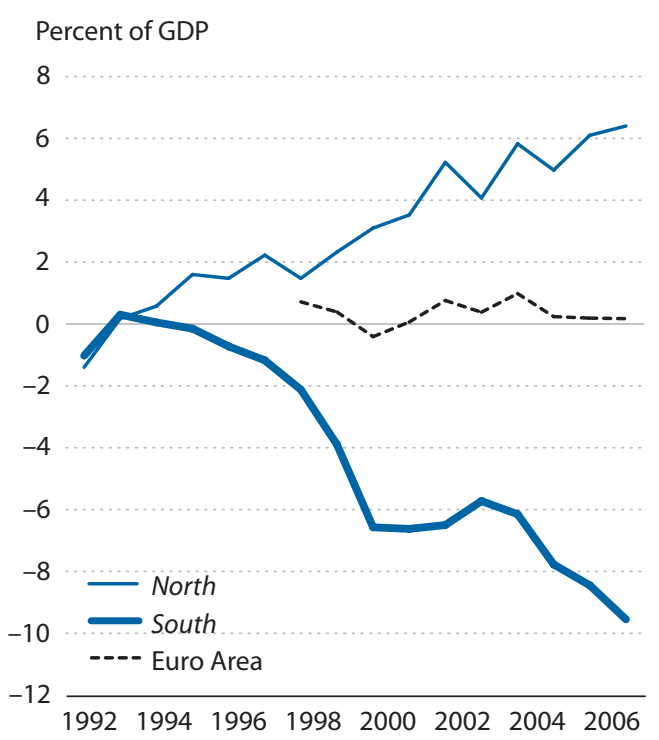

can by approximation treat the euro area as a closed economy and confine our analysis of current account imbalances to the euro area countries. Second, we note that some countries within the euro area have substantial and persistent current account surpluses and others have substantial and persistent current account deficits. We focus on the average behavior of two rather extreme groups in the euro area in this respect. On the one hand, we consider Austria, Finland, Germany, and the Netherlands as one group and call this North. All four countries are characterized by substantial and growing current account surpluses, especially from the early 2000s onward. On the other hand, Greece, Ireland, Portugal, and Spain form a group called South. These four countries have large and increasing current account deficits over time..

To construct the two groups, we used a clustering method using data for the 11 initial euro area members plus Greece, which entered in 2000. The five countries that entered later have been excluded from the analysis. Clustering was done for both current account data and private savings data and for both levels and first differences. All four cluster analyses put Austria, Finland, Germany, and the Netherlands in one group and Greece, Ireland, Portugal, and Spain in another. Allocation of Belgium, France, Italy, and Luxembourg to one or the other cluster varies, depending on the specification used. In the remainder of this paper, we use the North and South groups as defined above and exclude the other four countries. $\underline{9}$

Figure 1 provides evidence of the persistently rising current account imbalances within the euro area. Since the signing of the Maastricht treaty in 1991, the average current account balance of North has continuously grown from a small deficit in 1992 to more than 6 percent of GDP in 2007, while at the same time the average current account of South has deteriorated from close to zero in the early 1990s to a sizable deficit of almost 10 percent of GDP in 2007. Throughout the paper we use unweighted averages for North and South to avoid German dominance in North 
Table 1

Current Account versus Public and Private Savings

\begin{tabular}{|c|c|c|c|c|c|c|}
\hline \multirow[b]{2}{*}{ Region } & \multicolumn{2}{|c|}{ Current account } & \multicolumn{2}{|c|}{ Net public savings } & \multicolumn{2}{|c|}{ Net private savings } \\
\hline & 1992-1998 & 1999-2007 & 1992-1998 & $1999-2007$ & 1992-1998 & 1999-2007 \\
\hline South & -0.7 & -6.8 & -5.7 & -2.1 & 5.0 & -4.7 \\
\hline North & 0.9 & 4.6 & -3.3 & -0.2 & 4.2 & 4.8 \\
\hline
\end{tabular}

NOTE: Values expressed as percent of GDP.

and Spanish dominance in South. $\frac{10}{}$ Note that we cannot literally interpret the imbalances in Figure 1 as bilateral imbalances between North and South because of the trade relations of both areas with other countries. Nevertheless, the figure does provide strongly suggestive evidence of a significant flow of capital from North to South.

The figure demonstrates that most of the current account divergence can be attributed to the period starting around 1998-99, which corresponds to the introduction of the euro as a common currency. For that reason, we split the overall period into two subperiods. The first, from 1992 through 1998, roughly covers the run-up to the euro area. The second, from 1999 through 2007, captures the actual euro area period. The first column of Table 1 confirms that, in the run-up to the euro area, current account differences were relatively minor, with an average deficit for southern countries of 0.7 percent of GDP compared with an average surplus for northern countries of 0.9 percent of GDP. Since the introduction of the euro, the respective average current accounts imbalances have drifted apart by more than 11 percent of GDP. Distinct groups of creditor and debtor countries have emerged.

\section{Savings and Investment}

We proceed along two lines to further explore the origins of current account imbalances in the euro area. First, we investigate the relative contributions of the private and public sectors through their savings and investment decisions to the evolution of current account balances. To this end, we use the following accounting identity:

$$
\text { Current account }=\text { Net public savings }+ \text { Net private savings. }
$$

Second, we explore the three major components - the trade balance, net factor income, and transfers-of the current account imbalances using the following equation:

$$
\text { Current account }=\text { Trade balance }+ \text { Net factor income }+ \text { Net transfers. }
$$

Equation (1) clearly demonstrates that a country's current account balance ultimately is the result of savings and investment decisions of the private and public sectors. Figures 2 and 3 show net public and private savings in North and South, respectively. In addition, columns 2 and 3 of Table 1 present the averages for the two subperiods considered. Several points stand out. In both North and South net public savings improve - that is, government deficits are reduced consider- 
Figure 2

\section{Net Public Savings (1992-2007)}

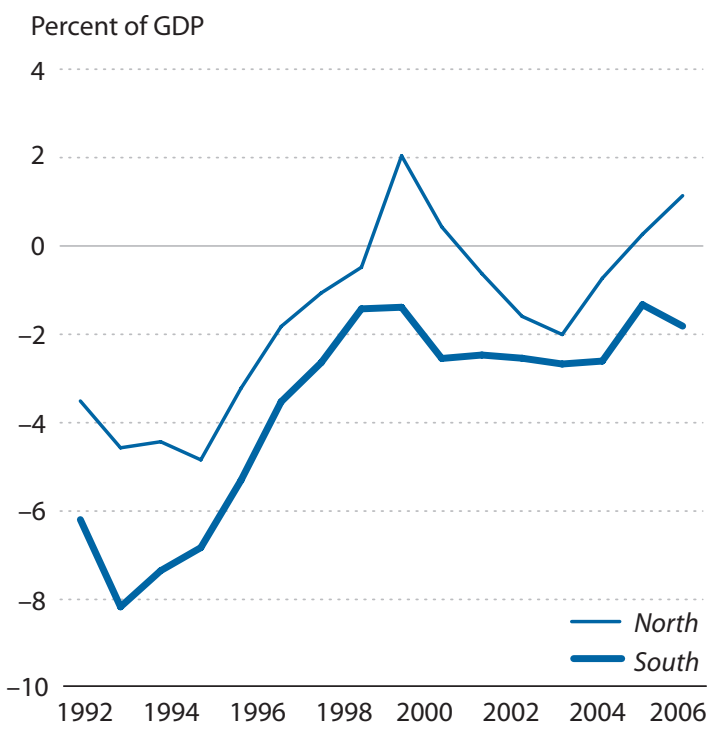

Figure 3

\section{Net Private Savings (1992-2007)}

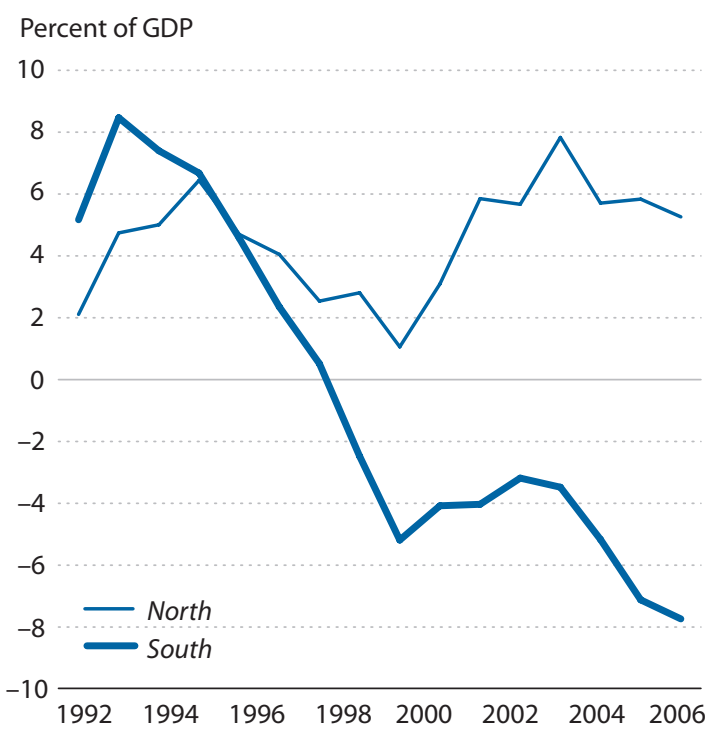

ably-between 1992 and 1998. After 1999, average deficits fluctuate around a mean of almost zero in North and about 2 percent in South. In summary, the evidence shows that both North and South implemented fiscal consolidation to comply with the requirements of the Maastricht treaty and the SGP. Note, though, that the average deficit of 2 percent in South in the second subperiod was realized in the upward phase of the business cycle. Business cycle adjustment would show that the structural deficit in South was too high over this period and insufficient to keep the government deficit below 3 percent should an economic downturn occur.

Both Figures 2 and 3 and Table 1 show that the strong divergence in current account imbalances from 1999 onward is due mostly to private-sector behavior. Net public savings in Southeven when they structurally fall short of those in North-actually improve from the first to the second subperiod by 3.6 percentage points. Simultaneously, the current account of South deteriorates from a negligible deficit of 0.7 percent to a large deficit of 6.8 percent as the current account of North improves from a surplus of 0.9 percent to 4.6 percent. $\underline{11}$

Figure 3 and the last two columns of Table 1 show that private-sector behavior in South explains most of the current account divergence. In North we find relatively steady private net savings that vary within a 3 percent margin around 5 percent of GDP over the entire period of 1992-2007. However, in South we see a tremendous deterioration of private net savings exceeding 16 percent of GDP: from a surplus of 8 percent of GDP in the early 1990s to a deficit of the same magnitude in 2007. The table shows that private net savings in South reversed from 5 percent of GDP in the first subperiod to -4.7 percent of GDP in the second subperiod.

It is particularly interesting to observe the difference in private-sector behavior in North and South between the two subperiods. In North, the improvement in government finances (as 


\section{Table 2}

\section{Nominal and Real Interest Rates}

\begin{tabular}{|c|c|c|c|c|c|c|}
\hline \multirow[b]{2}{*}{ Region } & \multicolumn{2}{|c|}{ Nominal rates } & \multicolumn{2}{|c|}{ CPI inflation } & \multicolumn{2}{|c|}{ Real rates } \\
\hline & 1992-1998 & 1999-2007 & 1992-1998 & 1999-2007 & 1992-1998 & 1999-2007 \\
\hline South & 9.7 & 4.6 & 4.0 & 3.3 & 5.7 & 1.3 \\
\hline North & 6.8 & 4.6 & 2.2 & 1.8 & 4.6 & 2.6 \\
\hline
\end{tabular}

NOTE: Values expressed as percent of GDP. CPI, consumer price index.

indicated by the 3.1-percentage-point increase in net public savings) has no noticeable influence on the level of net private savings, which remain roughly constant across subperiods. In South net public and private savings rates move in opposite directions. While the fiscal consolidation imposed by the Maastricht treaty and SGP to some extent disciplined public net savings, the growth of net private spending more than offset the improvement of government finances, resulting in a strongly deteriorating current account. The reduction in net private savings was probably induced in some part by lower real interest rates in South upon entry into the euro area and more general financial liberalization and the consequent increased availability of financial assets. $\underline{12}$

Table 2 summarizes nominal and real interest rate behavior for North and South. North effectively serves as the nominal anchor to the euro area. Its inflation rate remains roughly stable over the whole period. The fall in nominal and real rates in North, in our view, reflects the worldwide fall in real rates in this period. Note that both nominal and real rates fall substantially more in South than in North. This reflects not so much a fall in inflation in South-as most inflation convergence had already been achieved before 1992-as a rise in creditworthiness due to the disappearance of previously substantial inflation and exchange risk premiums. One could argue the fall in the real interest rate is the main driver of the increased private spending and the corresponding current account deficit in South. The fact that Jaumotte and Sodsriwiboon (2010) fail to find a significant interest rate coefficient in their panel regression framework creates some doubt about the strength of this argument. Moreover, it raises the puzzle of why the combined effect of higher government savings and a lower real rate did not increase spending in North. A possible explanation is the presence of heterogeneity in time preference and risk aversion across countries. We return to that observation later.

To further shed light on the dynamics of net private savings, we divide them into gross savings and investment in Figures 4 and 5, respectively, and Table 3. In North, gross private savings and investment rates have remained largely unchanged over the past one and a half decades. Private saving rates fluctuate around 23 percent of GDP, while private investment rates are 18.5 percent of GDP on average. This in itself is an interesting result: Neither the preparation for nor the introduction of a common currency (with all its far-reaching consequences) seems to have implications for the savings and investment behavior of households and firms in North.

In South, developments are fundamentally different. Figure 4 shows that the strong deterioration of private net savings rates can be primarily attributed to the savings behavior of the private sector. $\underline{13}$ The private savings rates dropped from a high of 24 percent of GDP in 1993 to almost 


\section{Figure 4}

\section{Gross Private Savings (1992-2007)}

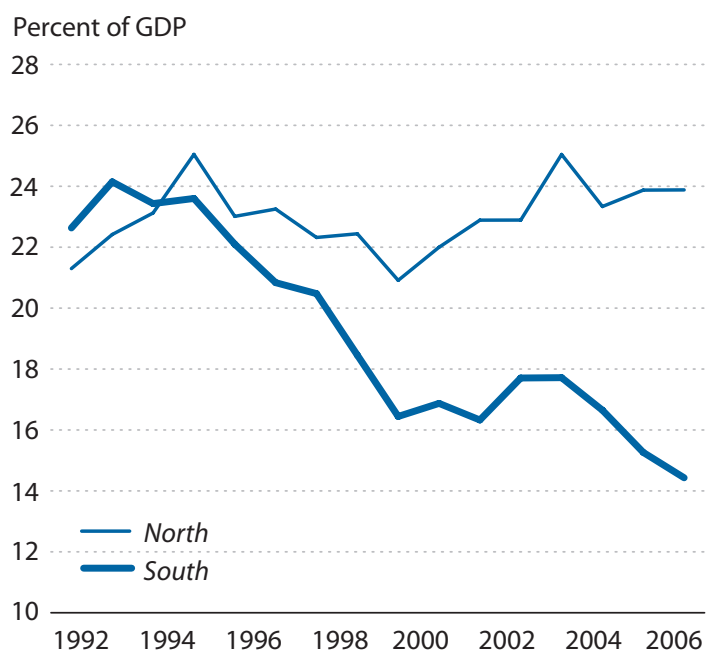

Figure 5

Private Investment (1992-2007)

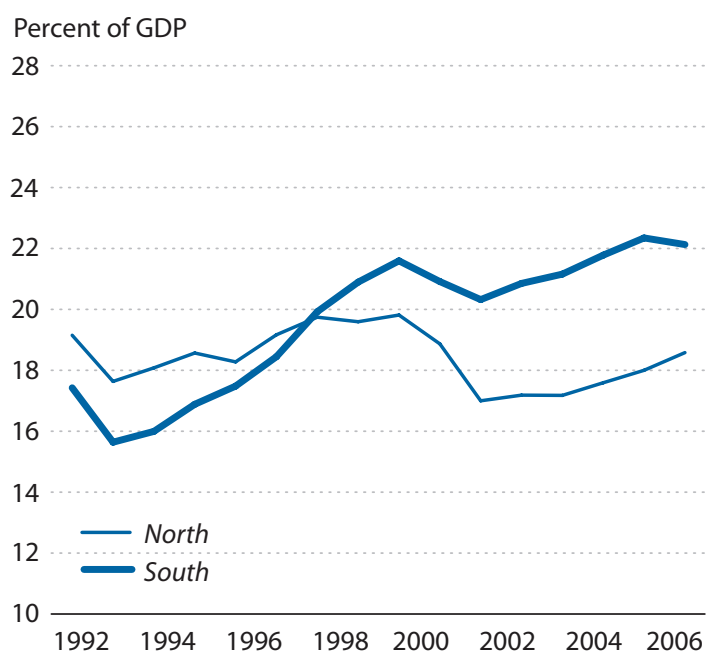

Table 3

Average Savings and Investment as a Percent of GDP

\begin{tabular}{|c|c|c|c|c|c|c|}
\hline \multirow[b]{2}{*}{ Region } & \multicolumn{2}{|c|}{ Net private savings } & \multicolumn{2}{|c|}{ Gross private savings } & \multicolumn{2}{|c|}{ Private investment } \\
\hline & 1992-1998 & 1999-2007 & 1992-1998 & 1999-2007 & 1992-1998 & 1999-2007 \\
\hline South & 5.0 & -4.7 & 22.4 & 16.7 & 17.4 & 21.4 \\
\hline North & 4.2 & 4.8 & 22.9 & 23.0 & 18.7 & 18.2 \\
\hline
\end{tabular}

14 percent in 2007; this is also confirmed by Table 3. In the first subperiod, North and South displayed almost the same average gross private savings rate of about 22.5 percent of GDP. However, with the introduction of the euro, this declined to an average of 16.7 percent of GDP in South, while it remained largely unchanged in North. Concomitant with falling private savings rates, we observe private investment growth in southern euro area countries that has contributed to the deterioration of their current accounts. The growth in private investment rates is largely confined to the period of the run-up to the euro's introduction and may have been triggered by the prospect of higher economic growth in the common currency area. Table 3 shows that the average private investment rate for southern euro area countries is 17.4 percent of GDP before the introduction of the euro and 21.4 percent of GDP thereafter.

\section{Current Account Composition}

In this section, we use equation (2) to investigate the current account dynamics in North and South from a different angle, decomposing the current account into its three main elements: the trade balance, net factor income, and net current transfers. In particular, the decomposition sheds light on the often-overlooked intertemporal character of the current account and reveals 
Figure 6

Net Foreign Assets (1992-2007)

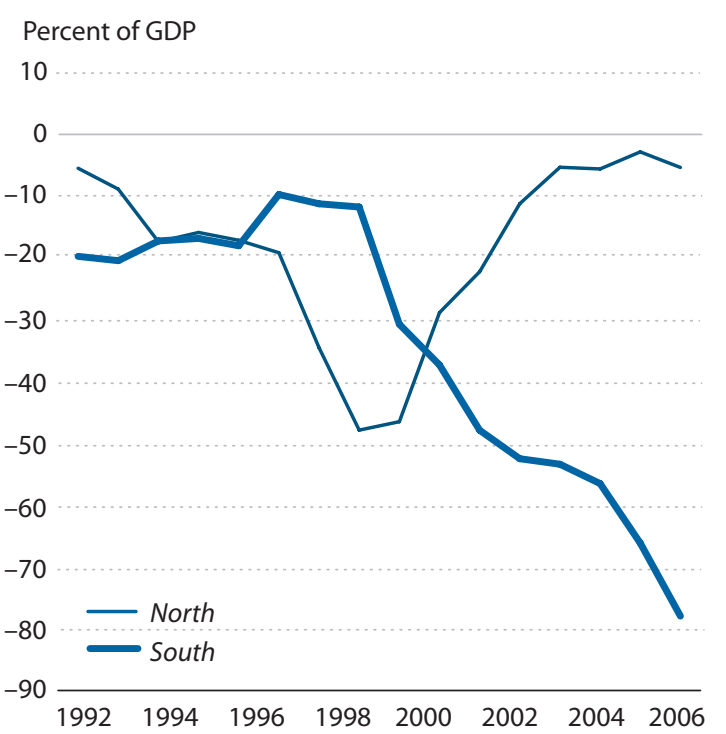

\section{Figure 7}

Net Factor Income (1992-2007)

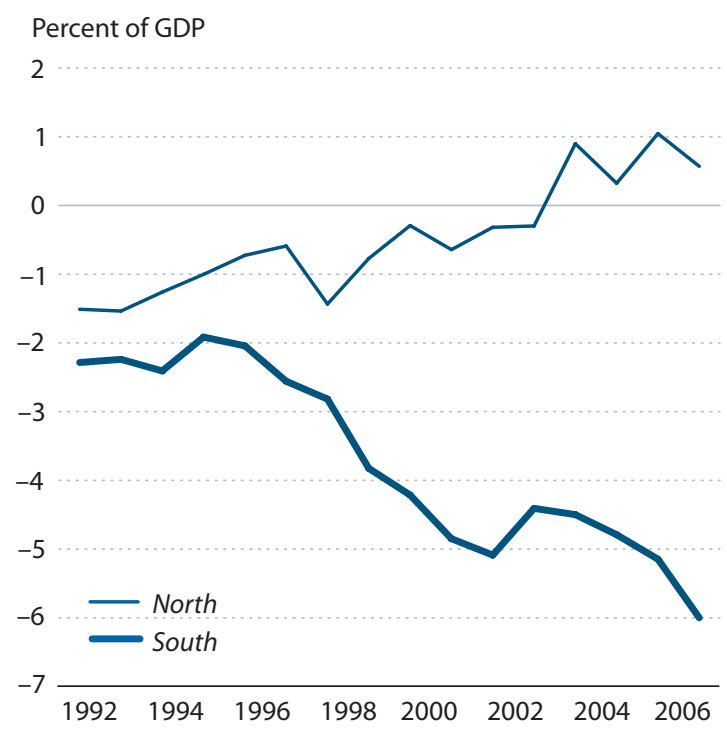

how past external imbalances translate into required future adjustment. $\stackrel{14}{ }$ The net factor income balance plays a crucial role in this respect.

A simple example suffices to illustrate the point. Assume a country has incurred a series of current account deficits in the past, leading to a net debtor position relative to the rest of the world. This scenario implies that the country needs to pay interest on its foreign debt to other countries. The interest rate payments show up in the net factor income balance and will-if not offset by a positive trade balance or transfer payments from the rest of the world-lead to further increases in foreign debt. A vicious circle will emerge, leading to an unsustainable situation at some point. The only way to break the vicious circle is to implement structural adjustments in the domestic economy that allow the country to obtain a positive trade balance-positive net exports of goods and services - to earn sufficient money to pay the interest on the debt. In addition, higher economic growth will reduce any foreign debt burden in terms of GDP.

Figure 6 shows the evolution of net foreign asset positions as a percentage of GDP over the 1992-2007 period. Until the late 1990s, the net foreign asset positions of North and South were roughly comparable and fluctuated between -10 and -20 percent of GDP. $\underline{15}$ However, the increasing divergence in current account patterns since 2000 has shown up in the respective net foreign asset positions. North's net foreign asset position improves each year because of current account surpluses, while South faces a decline in net foreign assets corresponding to its persistent current account deficits. The 2007 average net foreign liabilities are close to 80 percent of GDP for South, with obvious consequences for its future net factor income payments.

Figures 7, 8, and 9 and Table 4 summarize the evidence on the breakup of the current account in its three components. Both Figure 7 and Table 4 directly show the impact of accumulated 
Figure 8

Trade Balance (1992-2007)

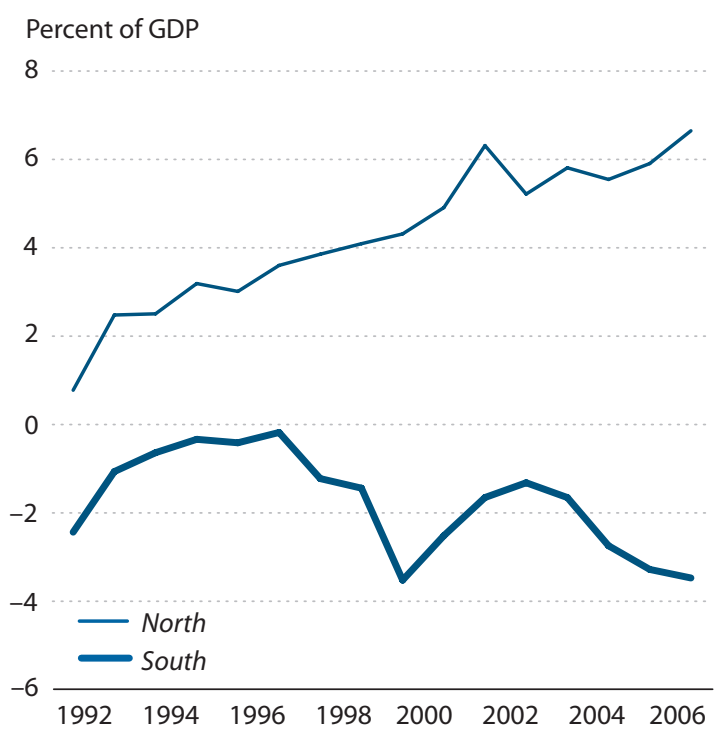

Figure 9

\section{Net Current Transfers (1992-2007)}

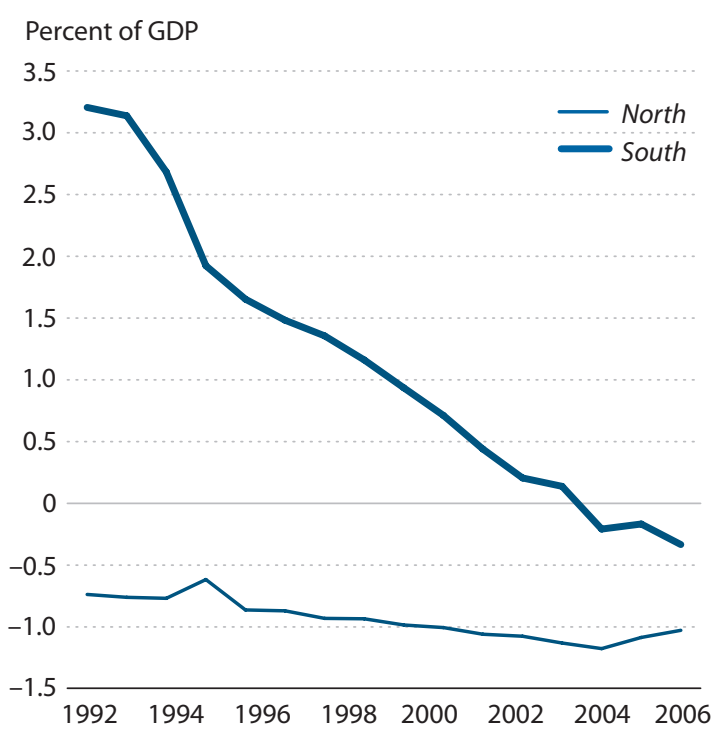

Table 4

Current Account Decomposition as a Percent of GDP

\begin{tabular}{|c|c|c|c|c|c|c|c|c|}
\hline \multirow[b]{2}{*}{ Region } & \multicolumn{2}{|c|}{ Current account } & \multicolumn{2}{|c|}{ Trade balance } & \multicolumn{2}{|c|}{ Net factor income } & \multicolumn{2}{|c|}{ Transfers } \\
\hline & 1992-1998 & 1999-2007 & 1992-1998 & 1999-2007 & 1992-1998 & $1999-2007$ & 1992-1998 & 1999-2007 \\
\hline South & -0.7 & -6.8 & -0.9 & -2.4 & -2.3 & -4.8 & 2.2 & 0.3 \\
\hline North & 0.9 & 4.6 & 2.8 & 5.4 & -1.2 & 0.1 & -0.8 & -1.1 \\
\hline
\end{tabular}

current account imbalances on net factor income payments, which by themselves reinforce current imbalances. Following the deterioration of its net foreign asset position, South must pay an increasing share of GDP to service its debt to foreign creditors, amounting to almost 6 percent of GDP in 2007. North, on the other hand, is a net recipient of factor income in the range of 0.5 to 1 percent of GDP in the latest years of our sample. Table 4 shows that about two-thirds of the current account deficit of South in the euro area period is due to its net factor income payments. Stated differently, in this period South on average borrows almost 5 percent of its GDP from the rest of the world simply to be able to service its debt.

Figure 8 presents trade balance developments for North and South. North consistently improves its trade balance from about 1 percent of GDP in 1992 to more than 6 percent of GDP in $2007 . \frac{16}{1}$ The average trade balance in South shows some swings with a trough close to -4 percent in 2000 and a subsequent peak of -1 percent in 2003. Since then, a negative trend has emerged, leading to a new low close to -4 percent in 2007. In comparison, the average trade deficit in the second subperiod is 1.5 percent higher than in the first one. Overall, the size of the trade deficit 


\section{Holinski, Kool, Muysken}

has remained limited so far. Nevertheless, before 2007 there is no sign that markets required trade surpluses to compensate for the strongly increasing net factor income payments from South. This again shows that the latter are directly passed on to the current account; from there, they feed back on the further accumulation of foreign debt. Clearly, this process is unsustainable and-without structural adjustment-will eventually lead to exploding foreign debt levels.

Figure 9 summarizes the evolution of net current transfers for North and South. To a large extent these transfers capture EU redistribution policies through, among others, structural cohesion funds. Two observations stand out: First, North pays transfers of about 1 percent of GDP over the entire period of analysis. On the other hand, South is a structural recipient of transfers only in the first period. Initially, net current transfers for South amount to over 3 percent of GDP, but they steadily decrease to about zero in 2007. We hypothesize the decline in net transfers for South is caused by the entry of many new low-income members from central and eastern Europe since the mid-1990s. With the EU expanded to include a group of countries with significantly lower income levels than the southern euro area countries, EU redistribution changes direction from south to east. Second, in the 1992-98 period net transfers to South went a long way in financing both South's trade deficit and net factor payments. During this period the sum of the latter two equals 3.2 percent of GDP, while the average net current transfers are 2.2 percent of GDP. However, when net transfers fall to about zero in the second subperiod, ongoing trade deficits and net factor payments directly feed into the current account, increasing net foreign liabilities and future net factor payments.

In summary, the increasing current account surpluses in North over the period are due to upward trends in the trade surplus and its net factor income receipts. The increasing current account deficits in South are driven mainly by the decline in transfers and the increase in net factor payments. The trade balance dynamics play a marginal role in South. Put differently, South has entered a vicious circle: Lower transfers did not lead to structural adjustment of the trade balance. Instead, South has been borrowing to allow it to maintain its positive net imports and finance its debt service. However, the borrowing only further increases the net foreign debt and subsequent interest payments, predictably leading to an unsustainable net foreign debt position in the future.

In the next section, we review the evidence that the observed current account patterns are part of a catching-up process of South with its neighbor, North.

\section{ALL A MATTER OF ECONOMIC CONVERGENCE?}

The neoclassical theory of intertemporal utility maximization as described previously suggests that diverging current accounts can be the natural consequence of a convergence process among countries with different levels of economic development. In particular, in the presence of integrated real and financial markets, countries with a lower per capita income would be expected to attract domestic and foreign investment since higher productivity and economic growth rates promise above-average rates of return. The productivity of the invested capital ensures that the accumulated foreign debt can ultimately be repaid. At the same time, these countries should consume more and consequently save less in anticipation of higher income growth in the future. 
Figure 10

\section{Terms of Trade (1992-2007)}

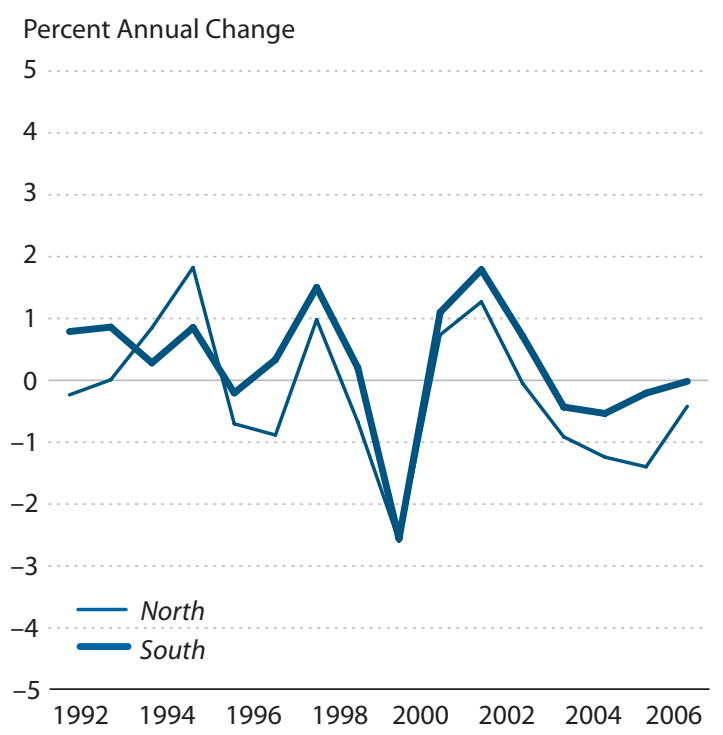

\section{Figure 11}

\section{Producer Price Inflation (1992-2007)}

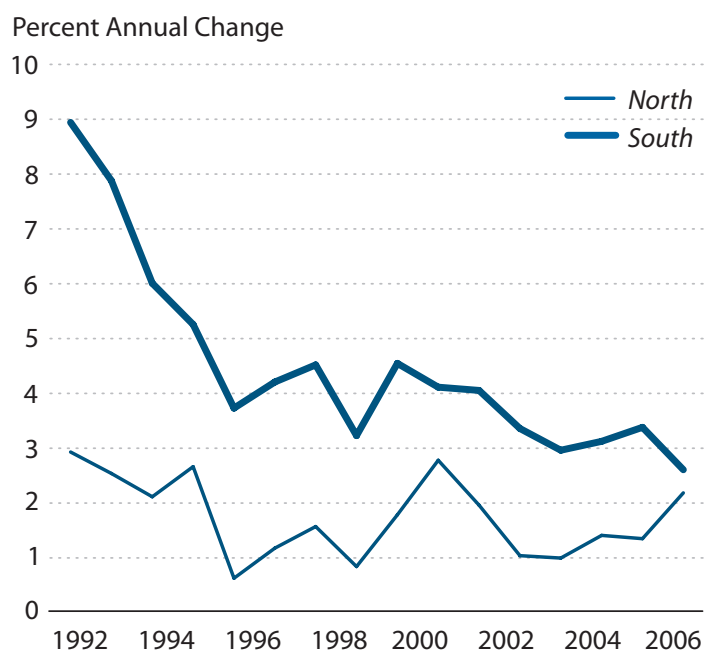

Thus, because of higher investment and lower savings, South should accumulate net foreign liabilities by running current account deficits, while North should act as a net lender-or investor-running current account surpluses. The pattern of capital flows from North to South observed in the data in principle is consistent with such a convergence process. In the same convergence process, South is expected to experience an inflation-induced appreciation of its real exchange rate relative to North. The nominal exchange rate between North and South is fixed because of the common currency. However, relatively high inflation in South will lead to an immediate real exchange rate appreciation and thus a less competitive international position and a lower trade balance and current account. 17 As a result, a current account deficit will emerge in South that matches the net inflow of funds in its capital account. Most importantly, at some point the increased investment in South needs to result in rising productivity and per capita income in South relative to North.

Figure 10 provides some evidence on the development of trade competitiveness in North and South using terms of trade data, where the terms of trade variable is defined as the ratio of export over import prices. The figure shows that the relative loss of overall international competitiveness in South compared with North has been limited to roughly 0.5 percent per year over the analysis period. $\frac{18}{2}$ This is consistent with our earlier finding that it is not the trade balance dynamics that cause the current account deficit in South but rather the loss of transfer receipts and the increased net factor payments.

Alternatively, Figure 11 presents producer price inflation rates in North and South. $\frac{19}{}$ During the entire 1992-2007 period, producer price inflation in South exceeds that in North by about 1.5 percent per year. ${ }^{20}$ It is inappropriate to use the difference in producer price inflation rates 
Figure 12

\section{Relative Real GDP per Capita (1992-2007)}

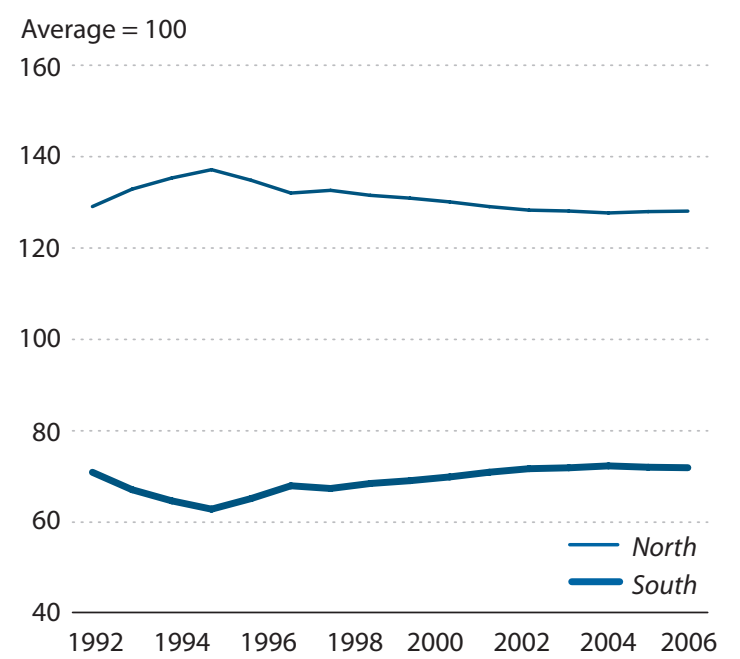

Figure 13

Relative Total Factor Productivity (1992-2007)

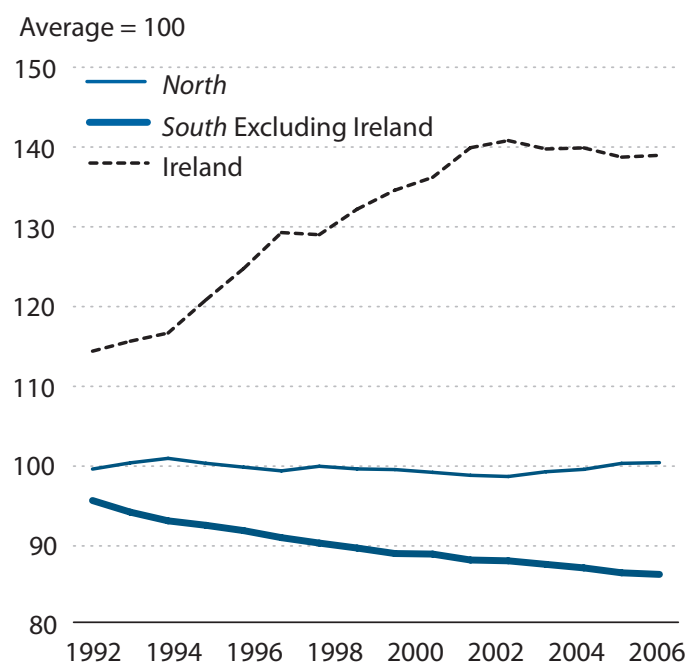

as a measure of overall competitiveness, since the trade balance of both South and North contains imports and exports traded with countries outside the euro area. However, it does show the bilateral real appreciation of South relative to North over the period.

Overall, the price evidence in a qualitative sense supports the predictions from neoclassical theory. South experiences consistently higher inflation than North, in principle facilitating a trade deficit to finance capital inflows. The link between the trade balance and the inflation differential appears weak, possibly due to trade links with other euro and non-euro countries.

Finally, we turn to the evidence with respect to per capita income and productivity. Figure 12 shows relative real GDP per capita for North and South. We find that real per capita income in North is about double that in South. Most importantly for our analysis, the data reveal little convergence over time despite (i) the European economic and monetary integration process and the introduction of the euro and (ii) the substantial net capital inflow-financed by current account deficits-in South. Figure 13 provides suggestive evidence on the reason for the lack of per capita income convergence: Total factor productivity in South falls relative to North over the years 1992 to 2007, in contradiction to theory. Ireland is an exception-with strongly increasing total factor productivity, in particular during the 1990s - and is therefore presented separately in Figure 13. $\underline{21}$

In summary, we conclude that the evidence in favor of structural economic convergence is weak as yet. In accordance with theory, capital has flowed from high-income North to low-income South between 1992 and 2007, even accelerating after the introduction of the euro in 1999. Also, real exchange rates in South have appreciated because of higher inflation rates, which is consistent with theory. Unfortunately, the cumulative inflow of capital-roughly equal to 50 percent of South's GDP-over the period 1999-2007 has not yet resulted in measurable gains of productivity and per capita income. Moreover, the evidence also shows that the increase in private invest- 
ment in South has remained limited despite the massive inflow of capital. Lower savings and higher consumption play an equally large role. In our view, the overall picture casts serious doubt on the hypothesis of automatic convergence in the euro area.

We thus suggest that the economic convergence theory can at best only partially explain the growing external imbalances in the euro area. In addition, Jaumotte and Sodsriwiboon (2010) provide convincing evidence that the increased availability of external funding because of financial liberalization and financial development in South also have contributed to South's increased foreign borrowing. Even then, it is likely that a gap remains between the fundamentals-based equilibrium current account imbalances and the actual imbalances in the euro area. Jaumotte and Sodsriwiboon (2010) estimate this gap to be close to 6 percent of GDP for South.

In our view, it is important to better understand the determinants behind the emergence of the unsustainable current account imbalances, not only because of the current precarious situation of southern euro area countries, but also to avoid such developments in future low-income entrants into the euro area.

One explanation for excessive borrowing in southern Europe is excessive risk-taking by European banks in both North and South and the failure of financial markets to recognize that the disappearance of exchange rate risk and inflation risk due to the introduction of the euro did not necessarily eliminate sovereign and country risk. Alternatively, one may argue that financial markets understood that southern euro area governments and countries were riskier than their northern euro area counterparts but expected the EU to bail out southern Europe in case of serious trouble, effectively eliminating the sovereign risk premium to almost zero.

It also needs to be recognized that the common monetary policy has a procyclical effect on the real interest rate in the short run, in addition to the too-low nominal and real interest rates due to underestimated sovereign risk. In the past decade, higher inflation in South has caused real rates there to be lower than in North, stimulating growth and spending and thereby reinforcing current account imbalances. $\underline{22}$

Our qualitative and descriptive analysis does not allow a precise estimate of the extent to which fundamentals, including inappropriately low real interest rates, can explain the persistent imbalances between North and South. However, so far no complete and satisfactory answer has been offered for the combination of large imbalances on the one hand and lack of convergence on the other. For this reason, we believe more attention should be paid to country heterogeneity, such as cross-country differences in time preference, planning horizon, and risk aversion. The evidence in this paper is consistent with agents in southern euro area countries having a stronger preference for current consumption, possibly due to a shorter planning horizon and a higher willingness to take risks with external debts. Recent empirical research by Guiso, Sapienza, and Zingales (2006) supports the relevance of this type of analysis. Controlling for a number of standard economic determinants of macroeconomics savings, they find that countries where more people state it is important to teach thriftiness to children have both statistically and economically significantly higher savings ratios. $\underline{23}$ We regard the descriptive analysis in this paper as a starting point for future empirical and theoretical research that emphasizes behavioral determinants of macroeconomic savings and investment patterns across countries. 


\section{WHY CURRENT ACCOUNT IMBALANCES SHOULD NOT BE DISREGARDED IN A COMMON CURRENCY AREA}

Given the qualitative nature of our analysis, we are unable to formally reject the convergence hypothesis. Nevertheless, we side with Arghyrou and Chortareas (2008) and Jaumotte and Sodsriwiboon (2010) that the growing current account imbalances in the euro area are cause for serious concern, deserve monitoring, and ultimately require an appropriate policy response. $\underline{24}$ We advance three important reasons for this position.

First, the developments in the euro area in the past decade, in our view, sufficiently demonstrate that private agents' decisions with respect to savings and investment can lead to large external deficits without automatically generating sufficient domestic economic growth and productivity gains. The result can be unsustainable net foreign liability positions that can only be redressed at substantial macroeconomic costs. Most likely it is a reflection of the fact that the euro area was not an optimal currency area from the start. Participating countries differ with respect to economic structure. Additional cross-country heterogeneity may derive from differences in time preference and risk aversion between agents in these countries.

Second, once unsustainable imbalances emerge, adjustment mechanisms are scarce and costly in the euro area. The standard advice to improve productivity and competitiveness in southern euro area countries — as advocated by Jaumotte and Sodsriwiboon (2010), for exampleis useful but difficult and unlikely to lead to a quick reversal of the accumulated current account imbalances in the short run. Alternative adjustment paths toward more sustainable current account positions within the euro area are not easy to achieve because of the design of the euro area itself. $\frac{25}{}$ Because all euro area countries use the same currency, a nominal exchange rate devaluation of South relative to North to quickly gain competitiveness is impossible. Without productivity gains, the burden of adjustment falls on prices and wages that need to fall and real interest rates that need to rise in southern relative to northern Europe. That is, southern countries can restore international price competitiveness and thus their external balances through a prolonged period of disinflation. Such a process is accompanied by a painful period of economic contraction and will take a number of years to resolve. Lower inflation in deficit countries will also result in higher real interest rates to encourage higher savings and less investment and consumption spending. The re-emergence of country risk premiums in financial markets works in the same way. Note that while higher real interest and lower inflation will be necessary in the long run to ensure a return to a sustainable equilibrium for countries that have let their net foreign debt run up too high, these same higher real interest rates and lower inflation rates will in the short run increase the southern euro area countries' current foreign debt burden and the probability of outright default. $\underline{26}$ The current situation in Greece-and also Italy-provides an alarming example.

Third, a strong, probably bidirectional link exists between current account imbalances and fiscal policy. The IMF (2011) shows that fiscal adjustments have large effects on external balances. On average, current accounts typically improve in countries with contractionary fiscal policies, whereas current accounts deteriorate in countries with more expansionary policies. This implies that interpreting the current account as the result of only private savings and investment decisions 
typically is too narrow a view. Past and current fiscal policies influence today's current account both directly and indirectly through the impact of fiscal policy on private savings and investment decisions.

A strong and often-overlooked argument in support of a semi-automatic link from the current account to fiscal policy is that private foreign credit risk can quickly become sovereign risk when banks are involved. Blanchard's (2007) point that no government intervention is required when private savings and investment decisions cause a current account imbalance disregards the fact that many of these private borrowing and lending decisions are made by banks, especially when cross-border credit is concerned. However, the past four years have shown that banking risk can easily be converted to sovereign risk, since a country's government-and its tax basewill ultimately need to provide the banking system's safety net. Even worse, banks that know they will be bailed out by their government may actually take on too much (foreign) debt to increase their expected returns. Obviously, a first-best response would be to adequately regulate financial institutions and markets to prevent such behavior. Experience shows, though, that even good regulation will not permanently prevent financial fragility and default.

In our view, in a common currency area-or an irrevocably fixed exchange rate system, for that matter-fiscal policy in the end will be forced to step in to address unsustainable current account imbalances. ${ }^{27}$ This is exactly what experience in the euro area over the past few years shows. To maintain and defend the euro area, northern euro area countries will need to bail out southern countries, willingly or not, and are doing so as witnessed by implicit and explicit guarantees and continuing emergency financial support. And they probably will need to keep doing so for a substantial period ahead.

Looking forward, the current crisis teaches two additional lessons. First, it clarifies that, within a currency area with substantial country heterogeneity, more fiscal policy coordination is required to prevent the buildup of unsustainable external imbalances. Moreover, while public discussion currently has focused almost exclusively on adjustment of the weaker-deficitcountries in South, both northern and southern euro area countries should recognize that changes in competitiveness and fiscal stance are a joint responsibility of and will affect both surplus and deficit countries. $\underline{28}$ Recognizing this joint responsibility, in our view, will greatly increase the economic and political stability of the euro area and hasten adjustment. Unfortunately, political recognition and support for such joint responsibility currently is virtually absent in the northern euro area countries.

\section{CONCLUSION}

In this paper, we provide a systematic analysis of the divergent pattern of current account imbalances in the euro area that emerged with the introduction of the euro as a common currency. Especially since 1999, we can identify two groups of euro area countries that were running average current account surpluses (North) and deficits (South) of 4.6 percent and -6.8 percent of GDP, respectively.

Viewed from the domestic side, most of the growth in the current account surplus in North arises as the result of substantial fiscal consolidation on the one hand and relatively unchanged private-sector savings and investment on the other. Simultaneously, North has been able to trans- 


\section{Holinski, Kool, Muysken}

late higher competitiveness into increasing trade surpluses and higher net factor income from abroad. For South, the decline in private-sector savings in terms of GDP by about 10 percentage points between 1992 and 2007 is the major driver of the considerable growth of the current account deficit, dominating the effect of higher net public savings. Most of the dynamics in South's current account arise from the trend-like increase in net factor income payments and decrease in net transfer receipts. Stated differently, South has been persistently borrowing from abroad to maintain its negative trade balance and pay the interest on its net debt. Particularly worrisome is the observation that South has not yet seemed able to convert its large inflow of foreign capital into a more a productive and competitive economy.

In our view, underlying fundamental economic factors cannot fully explain the observed imbalances in the euro area even accounting for financial liberalization and too-low real interest rates in South as a result of the start of the euro area. The common argument of economic convergence does not provide a satisfactory explanation of our observations. Potentially, excessive risk-taking by banks and the procyclical effect of the common monetary policy in the euro area may have contributed to the large current account imbalances just before the global financial crisis in 2008. In addition, we believe more research is needed to uncover the potential role of country (agent) heterogeneity in terms of time preference and risk aversion.

In summary, we conclude that systematic monitoring of external imbalances and implementing better coordinated policies to prevent the emergence of unsustainably large imbalances is advisable for the following reasons: First, country heterogeneity and the absence of optimal currency area characteristics may lead to the emergence of large current account imbalances without automatic gains in productivity and economic growth to sustain these imbalances. Second, the absence of sufficient market-based adjustment mechanisms substantially increases the costs of ultimate adjustment toward more sustainable current account positions. And finally, large external imbalances, particularly through the major role of the banking system, potentially have strong negative consequences for fiscal policy.

\section{NOTES}

1 Between 1999 and 2011, 6 other EU countries have entered the euro area and introduced the euro as their currency, putting the total at 17 member countries as of November 2011.

2 As the focus of the paper is on macroeconomic external imbalances, we do not further elaborate on the sovereign debt crisis in some euro area countries.

$\underline{3}$ See Keijzer and Kool (2009) for a recent overview of this literature.

4 In addition, a transitory current account deficit may arise when a country wants to retain a stable consumption path in the face of a one-time adverse economic shock.

$\underline{5}$ Note that an alternative, mostly empirical, literature exists that directly links current account imbalances to financial fragility and crises; see, for instance, IMF (2009).

6 Blanchard (2007) takes a similar position with respect to the euro area countries.

$\underline{7}$ We limit ourselves to the period before 2007 to be able to abstract from possible consequences of the global financial crisis for euro area current account imbalances.

8 Obviously, quite a bit of internal heterogeneity exists among the countries in South in other economic dimensions-for example, their government debt. The same is true for North. In this paper, we abstract from these differences. For a discussion of current economic differences among countries in South, see Gros (2010). 


\section{Holinski, Kool, Muysken}

9 Analysis not included here shows that the results remain qualitatively the same when we include Belgium, France, and Luxembourg under North and Italy under South.

10 The results are qualitatively similar when we use GDP-weighted figures, which are available from the authors upon request.

11 So far, the global financial crisis has had little impact on relative current account imbalances within the euro area. In 2010, the average current account surplus in North amounted to 4.3 percent, whereas the average deficit in South equaled 6.0 percent. These numbers are quite close to the 1999-2007 averages in Table 1, though somewhat smaller than in 2007. Ireland is an exception, as it managed to run a balanced current account in 2010.

12 Jaumotte and Sodsriwiboon (2010) find a significant negative effect of financial liberalization on the current account in a panel regression framework for southern euro area countries. In addition, they report significant negative effects of entry into the European Monetary Union and the euro area for southern euro area countries on their current account using dummy variables but no significant role for interest rates.

13 This finding is consistent with Jaumotte and Sodsriwiboon (2010).

14 In our analysis we abstract from adjustment through valuation effects on foreign assets and liabilities because of the absence of nominal exchange rate adjustment in the euro area. For an empirical and theoretical discussion of valuation effects in the external adjustment process, see, among others, Lane and Milesi-Ferretti (2005) and Holinski, Kool, and Muysken (2009).

15 In 1997-99 North experiences a substantial fall in net foreign assets despite positive current account balances as shown in Figure 1. This is most likely due to valuation effects on North's foreign assets and liabilities in non-euro area countries.

16 Obviously, this is not just due to net exports to South. North also runs large trade surpluses with countries outside the euro area such as the United Kingdom and the new central European EU members. This situation again exemplifies that the numbers we present cannot be interpreted as direct bilateral relations between North and South.

17 Two complementary theories exist to explain the inflation-induced loss of international competitiveness during the convergence process. For a supply-side approach, see Balassa (1964) and Samuelson (1964); for a demand-side approach, see Baumol and Bowen (1966).

18 Using a real effective exchange rate approach, Jaumotte and Sodsriwiboon (2010) find an average annual loss of competitiveness of 1.5 percent for Greece, Spain, and Portugal over the period 1999-2008.

19 A caveat pertains to the use of producer prices here as these also contain nontradable goods prices.

20 This is consistent with the difference in CPI inflation rates in Table 2 and the evidence in Jaumotte and Sodsriwiboon (2010).

$\underline{21}$ Supporting our conclusion, Gourinchas (2002) concludes that economic convergence in the euro area had already more or less come to a halt in 1996.

22 Jaumotte and Sodriwiboon (2010) fail to find a significant real interest rate effect on current account balances in their panel regression framework.

23 Other examples include Alesina, Di Tella, and MacCulloch (2004), who demonstrate that left-wing voters in Europe are more hurt by (income) inequality than left-wing voters in the United States, and Kwok and Tadesse (2006), who use Hofstede's (2001) uncertainty avoidance index to explain cross-country differences in the design of financial systems. See van Hoorn (2011) for a recent overview of research into heterogeneous preferences.

24 Our subsequent discussion assumes the euro area will be defended and maintained. If not, the consequent changes in institutional design will lead to substantially different adjustment mechanisms. This issue is outside the scope of our paper.

$\underline{25}$ One could interpret this as one of the distortions referred to by Blanchard (2007).

26 Wealth effects may also act as an important adjustment channel, with higher net foreign debt acting as a drag on spending. Until recently, this channel does not seem to have been a powerful transmission channel in either southern or northern Europe.

27 We refer to Blanchard (2007) and the IMF (2011) for supporting arguments along this line.

$\underline{28}$ For that matter, the buildup of cumulative current account deficits in South could not have happened without the simultaneous buildup of cumulative current account surpluses in North. 


\section{Holinski, Kool, Muysken}

\section{REFERENCES}

Ahearne, Alan; Schmitz, Birgit and von Hagen, Jürgen. "Current Account Imbalances in the Euro Area," in Anders Aslund and Marek Dabrowksi, eds., Challenges of Globalization: Imbalances and Growth. Chap 1. Washington, DC: Peterson Institute for International Economics, 2007, pp. 41-57.

Alesina, Alberto; Di Tella, Rafael and MacCulloch, Robert. "Inequality and Happiness: Are Europeans and Americans Different?" Journal of Public Economics, August 2004, 88(9-10), pp. 2009-42.

Arghyrou, Michael and Chortareas, Georgios. "Current Account Imbalances and Real Exchange Rates in the Euro Area." Review of International Economics, 2008, 16(4), pp. 747-64.

Balassa, Bela. "The Purchasing-Power Parity Doctrine: A Reappraisal." Journal of Political Economy, December 1964, 72(6), pp. 584-96.

Baumol, William and Bowen, William. Performing Arts: The Economic Dilemma-A Study of Problems Common to Theater, Opera, Music and Dance. Cambridge, MA: MIT Press, 1966.

Blanchard, Olivier. “Current Account Deficits in Rich Countries." IMF Staff Papers, 2007, 54(2), pp. 191-219.

Blanchard, Olivier and Giavazzi, Francesco. "Current Account Deficits in the Euro Area: The End of the Feldstein-Horioka Puzzle?" Brookings Papers on Economic Activity, 2002, 33(2), pp. 147-86.

Clarida, Richard H. G7 Current Account Imbalances: Sustainability and Adjustment. Chicago: University of Chicago Press, 2007.

Feldstein, Martin and Horioka, Charles. "Domestic Saving and International Capital Flows." Economic Journal, June 1980, 90(358), pp. 314-29.

Gourinchas, Pierre-Olivier. Comment on "Current Account Deficits in the Euro Area: The End of the Feldstein-Horioka Puzzle?" Brookings Papers on Economic Activity, 2002, 33(2), pp. 196-206.

Gros, Daniel. "Adjustment Difficulties in the GIPSY Club." CEPS Working Document No. 326; Centre for European Policy Studies, March 5, 2010.

Guiso, Luigi; Sapienza, Paola and Zingales, Luigi. “Does Culture Affect Economic Outcomes?" Journal of Economic Perspectives, Spring 2006, 20(2), pp. 23-48.

Hofstede, Geert. Culture's Consequences: Comparing Values, Behaviors, Institutions and Organizations Across Nations. Second Edition. Thousand Oaks, CA: Sage, 2001.

Holinski, Nils; Kool, Clemens and Muysken, Joan. "International Portfolio Balance-Modelling the External Adjustment Process." METEOR Research Memorandum RM/09/033, August 10, 2009.

International Monetary Fund. "Lessons for Monetary Policy from Asset Price Fluctuations," in World Economic Outlook: Crisis and Recovery. 2. Chap. 3. April 2009, pp. 93-120; www.imf.org/external/pubs/ft/weo/2009/02/pdf/c3.pdf.

International Monetary Fund. "Separated at Birth? The Twin Budget and Trade Balances," in World Economic Outlook: Slow Growth, Rising Risks. 2. Chap. 4. September 2011, pp. 135-60; www.imf.org/external/pubs/ft/weo/2011/02/pdf/c4.pdf.

Jaumotte, Florence and Sodsriwiboon, Piyaporn. "Current Account Imbalances in the Southern Euro Area." IMF Working Paper No. 10/39, International Monetary Fund, June 2010; www.imf.org/external/pubs/ft/wp/2010/wp10139.pdf.

Keijzer, Linda and Kool, Clemens. "International Capital Mobility: Linking the Feldstein-Horioka Puzzle to the Trade and Equity Home Bias Puzzles." Cambridge Journal of Regions, Economy and Society, 2009, 2(2), pp. 211-28.

Kwok, Chuck and Tadesse, Solomon. "National Culture and Financial Systems." Journal of International Business Studies, March 2006, 37, pp. 227-47.

Lane, Philip and Milesi-Ferretti, Gian. "A Global Perspective on External Positions." NBER Working Paper No. 11589, National Bureau of Economic Research, August 2005; http://econpapers.repec.org/paper/iisdispap/iiisdp079.htm.

Samuelson, Paul. “Theoretical Notes on Trade Problems.” Review of Economics and Statistics, May 1964, 46(2), pp. 145-54.

van Hoorn, André. "The Economics of Preference Heterogeneity." Ph.D. Thesis, University of Nijmegen, 2011; http://repository.ubn.ru.nl/bitstream/2066/84548/1/84548.pdf. 


\section{Nils Holinski}

http://www.fdewb.unimaas.nl/algec/phd students AE2.asp

\section{Clemens Kool}

Professor of Finance and Financial Markets at the Utrecht University School of Economics

http://www.uu.nl/rebo/medewerkers/CJMKool

\section{Research Focus}

Clemens Kool's research and teaching interests focus on monetary theory and policy, European monetary and financial integration, the global financial infrastructure, the working of international financial markets, banks and other financial institutions, and the role therein of financial regulation and supervision.

\section{Recent Research}

"Central Bank Transparency and the Crowding Out of Private Information in Financial Markets," Journal of Money, Credit, and Banking, June 2011, 43(4), pp. 765-74.

"The Impact of International Portfolio Composition on Consumption Risk Sharing., TKI working paper, 2011.

"The Sustainability of Global Financial Imbalances," in The Quest for Stability: the Macro View, SUERF Study, Vienna/Brussels, May 2010, pp. 61-85.

"Effects of Heterogeneity on Bank Efficiency Scores,", European Journal of Operational Research, 2009, 195, pp. 251-61.

\section{Joan Muysken}

http://www.maastrichtuniversity.nl/web/Main/Sitewide/Content/MuyskenJoan.htm 